\title{
Sequential development of human fetal pancreatic islets of langerhans cells: A histopathological study
}

\author{
Smita Singh Banerjee', Vasanti Arole ${ }^{2}$ \\ ${ }^{1}$ Assistant Professor, Department of Anatomy, College of Medicine \& J.N.M. Hospital, WBUHS, Kalyani, Nadia, \\ West Bengal-741235, India, ${ }^{2}$ Professor, Department of Anatomy, Dr. D. Y. Patil Medical College, Hospital and \\ Research Center, Dr. D. Y. Patil Vidyapeeth, Pune, Maharashtra, India
}

Background: Knowledge of normal development pattern of various endocrine cells of the human pancreas is of paramount importance, due to its implication during replacement therapies in the treatment of diabetes mellitus. Development related literature of fetal pancreas is scanty due to ethical and technical difficulties to obtain fetuses. Aims and Objectives: The present study was conducted on 49 fetuses from gestational weeks 10 to 40 to obtain the sequential appearance and arrangement of islets of langerhans cells of pancreas. Material and Methods: Forty nine fetuses were collected in formal saline immediately after abortion, medical termination of pregnancy or premature delivery. The fetal pancreas was processed for paraffin blocks. Sections were taken and stained with Haematoxylin and Eosin as well as Gomori's modified Aldehyde Fuchsin stain and observed under light microscope. Results: Islets were initially a small number of cells with Alpha cells, which were seen at $10^{\text {th }}$ week of gestation. Beta cells were identified in the islets of fetuses around 16 weeks of gestation. Delta cells were observed from 17 weeks onwards and islets appeared as a group from the beginning of $19^{\text {th }}$ week. Conclusion: In the present study we observed a sequential development of Alpha, Beta and Delta cells and subsequent grouping of the islets. The exact gestational time of appearance of above islet cells and their encapsulation can add to the existing knowledge data base for successful transplant of pancreas in patients of insulin dependent diabetes mellitus.

Access this article online

Website:

http://nepjol.info/index.php/AJMS DOI: 10.3126/ajms.v9i5.20292 E-ISSN: 2091-0576

P-ISSN: 2467-9100

Key words: Histogenesis; Pancreas; Islets of langerhans; Diabetes mellitus

\section{INTRODUCTION}

The meticulous selection of an appropriate developmental stage of fetal pancreas is of paramount importance not only for the successful transplant of pancreas in patients of insulin dependent diabetes but to study the histological variations that might have occurred as a result of various maternal drug intake during the entire course of pregnancy. ${ }^{1}$

Islets of langerhans of pancreas are having endocrine function and mostly confined to the tail of pancreas. ${ }^{2}$ Around 200 millions of people worldwide currently affected from diabetes, in all its forms and this figure is expected to raise further. ${ }^{3}$ The pancreas is a retort shaped gland ${ }^{4}$ which develop from 2 evaginations of the foregut fusing to form a single organ. A dorsal pancreatic bud proliferates into the dorsal mesogastrium and a ventral bud evaginates in close proximity to the liver primordium. At 5 weeks differential growth of duodenum wall, results in movement of ventral pancreatic bud to the right side \& ultimately to a dorsal position. The primitive duct epithelium provides the stem cell population of all the secretory cells of the pancreas. It gives rise to the alpha cells producing glucagon, beta cells producing insulin, delta cells producing somatostatin. Initially these endocrine cells are located in the duct walls or in buds developing from them, later they accumulate in pancreatic islets. ${ }^{5}$

The exact \& specific time of appearance of these islet cells in the embryonic life is still a grey zone. The present 
study purports to find the time \& age of appearance of these cells with respect to gestational age of the fetuses. The pancreas as mentioned earlier has both exocrine \& endocrine components, which form the majority of the gland. ${ }^{6}$

The endocrine cells in the islets of langerhans are arranged in cords \& clumps, between which are found delicate connective tissue fibers \& a rich capillary network. The pancreatic Islets contain several hormone secreting cells, however with the routine histological preparation individual cells cannot be identified \& hence the need for special stains. With modified aldehyde fuchsin staining procedure that has been used as special stain for islets in the present study- alpha cells stain yellow, beta cells stain deep purple violet, delta cells green, nucleus stain blue black and PAS is for zymogen granules.

\section{MATERIAL AND METHODS}

The study was started after obtaining ethical committee clearance of the institution. 49 aborted human fetuses of different gestational age groups starting from 10 weeks upto 40 weeks with no obvious congenital abnormality has been obtained from the labour room of Gynaecology and Obstetrics Dept. of Pad. Dr. D. Y. Patil Medical College \& Hospital, Pimpri, Pune after a detailed maternal history and proper consent from both the parents. These were arranged randomly into 7 gestational age groups with equal number of fetuses in each group (Table 1). None of the mothers suffered from any medical illness during pregnancy. The age of the fetuses were decided by measuring the crown rump length (CRL).

The fetuses were collected in formal saline immediately after abortion, medical termination of pregnancy or premature delivery. The fetal pancreas was dissected out carefully and fixed in 10\% formal saline for 48 hours and thereafter processed for paraffin blocks. Sections of 5 micron thickness were taken and stained with Haematoxylin and Eosin as well as Gomori's Modified Aldehyde Fuchsin stain and observed under light microscope.

\begin{tabular}{|c|c|c|}
\hline Group & Gestational Weeks & No. of Fetuses \\
\hline Group I & 10-14 weeks & 7 \\
\hline Group II & $14.1-16$ weeks & 7 \\
\hline Group III & 16.1-19 weeks & 7 \\
\hline Group IV & 19.1-23 weeks & 7 \\
\hline Group V & 23.1-26 weeks & 7 \\
\hline Group VI & 26.1-33 weeks & 7 \\
\hline Group VII & $33.1-40$ weeks & 7 \\
\hline
\end{tabular}

\section{Method of tissue processing}

- Foetal tissue kept in 10\% formal saline (for tissue fixation) for 48 hours

- Washing of tissue done for $2 \mathrm{hrs}$ under running tap water

Tissue put in following solutions as per sequence $\&$ number of hours shown:

- $\quad 50 \%$ alcohol $2 \mathrm{hrs}$

- $70 \%$ alcohol overnight

- $80 \%$ alcohol $2 \mathrm{hrs}$

- $\quad 95 \%$ alcohol $2 \mathrm{hrs}$

- Absolute alcohol I for $1 \mathrm{hr}$

- Absolute alcohol II for $1 \mathrm{hr}$ (Ascending grades of alcohol were used to dehydrate the tissue)

- Xylene I for $1 \mathrm{hr}$

- Xylene II for $1 \mathrm{hr}$

- Paraffin I overnight

- Paraffin bath II for 2 hrs

- Block prepared

- Sections of 5 micron thickness were taken

- the sections were lifted on a glass slide

- dried at room temperature

\section{Staining procedure}

\section{Haematoxylin and Eosin stain}

It was used to see the general structure of the pancreas showing acini, connective tissue, lobules, ducts \& Islets of Langerhans

- The slides were put in Xylene $1 \mathrm{hr}$ to remove paraffin from the tissue

\section{Hydration of tissue was done as follows}

- Absolute alcohol 3dips

- $\quad 95 \%$ alcohol 3 dips

- $80 \%$ alcohol 3dips

- $70 \%$ alcohol 3dips

- $\quad 50 \%$ alcohol 3dips

- Distilled water 3dips

- Haematoxyline 10 mins

- Running water 10 mins to wash excess haematoxylin

- $\quad$ Eosin 2 mins

- Sections were washed in running tap water

For mounting, the sections were dehydrated as follows

- $50 \%$ alcohol 3 dips

- $70 \%$ alcohol 3 dips

- $80 \%$ alcohol 3 dips

- $\quad 95 \%$ alcohol- 3 dips

- Absolute alcohol- 3 dips

- Xylene I

- Xylene II

- Mounted with DPX and covered with coverslip

- Care was taken while mounting the sections to avoid air bubbles 


\section{Gomori's aldehyde fuchsin stain}

It was used to see the different types of cells in the Islets of Langerhans. G. Gomori $(1941)^{7}$ studied differential stains on human pancreatic islets.

Gomori's aldehyde fuchsin stain was prepared as follows

- Basic fuchsin 0.5gm

- $70 \%$ alcohol $100 \mathrm{ml}$

- Conc. $\mathrm{HCl} 1 \mathrm{ml}$

- Paraldehyde $1 \mathrm{ml}$

Procedure

- Dye was dissolved in alcohol

- Added acid \& paraldehyde

- Left at room temperature for 24-72 hrs until stain assumes deep purple colour indicating fitness for use

- $\quad$ Stain stored in refrigerator at 4 degrees $C \&$ replaced after 2-3months

\section{Technique}

- $\quad$ sections taken to water

- treated with lugols iodine for $10 \mathrm{~min}$

- $\quad$ rinsed in tap water \& decolourised in $2.5 \%$ sodium thiosulphate for $2 \mathrm{~min}(2.5 \mathrm{gm}$ sodium thiosulphate + $100 \mathrm{cc}$ distilled water)

- washed in tap water followed by $70 \%$ alcohol

- $\quad$ stained in a jar of aldehyde fuchsin for $10 \mathrm{~min}$

- washed well in 95\% alcohol

- followed by water

- $\quad$ nuclei were stained with Celestine blue \& haemalum

Preparation of celestine blue haemalum sequence

- Celestine blue B- 0.5gm

- Ferric ammonium sulphate(iron alum)-5gm

- Glycerine- $14 \mathrm{ml}$

- Distilled water-100ml

\section{METHOD}

- Iron alum dissolved in water without heat

- Celestine blue added \& boiled for $3 \mathrm{~min}$

- $\quad$ Filtered when cool \& glycerine added)

- Washed in water, differentiated briefly in acid alcohol(dips) \& washed well in tap water rinsed with distilled water \& counterstained with Orange G- Light green for $45 \mathrm{sec}$

Preparation of Orange G- Light Green

- $\quad$ Light green $0.2 \mathrm{gm}$

- Orange G $1 \mathrm{gm}$

- Phosphotungstic acid 0.5gm

- Glacial acetic acid $1 \mathrm{ml}$

- Distilled water $100 \mathrm{ml}$
Stock solution

- $\quad$ Light green crystals $0.2 \mathrm{gm}$

- Distilled water 100cc

- Glacial acetic acid $0.2 \mathrm{cc}$

Working solution

- $10 \mathrm{cc}$ of stock solution

- $50 \mathrm{cc}$ of distilled water

- $\quad$ Slides were rinsed briefly with $0.2 \%$ acetic acid $(0.1 \mathrm{ml}$ of acetic acid $+50 \mathrm{ml}$ of alcohol) followed by $95 \%$ alcohol

- dehydrated in absolute alcohol

- cleared in xylene \& mounted in a synthetic resin medium

Results expected

Different cells of Islets of Langerhans stained differently

- beta cells- deep purple violet

- alpha cells- yellow

- D cells- green

- Nuclei- blue black

- Collagen- green

\section{RESULTS}

Fallowing observations were made after detail histopathological study.

10 weeks to 14 weeks foetus. (Figure 1)

- Few cells in between the acini are forming islets

- Scattered rounded endodermal cells are seen amongst the mesenchymal cells which may form acini or cells of islets.

- Alpha cells have started appearing in the islets

14. 1 weeks to 16 weeks foetus. (Figure 2)

- Alpha \& Beta cells seen in the islet group of cells identified as yellow coloured \& violet coloured cells respectively when stained with Aldehyde Fuchsin.

- Alpha cells are larger than Beta cells

- Plenty of connective tissue with scattered rounded endodermal cells amidst mesenchymal cells are seen

16.1 weeks to 19 weeks foetus. (Figure 3)

- Islets are seen as individual cells among the group of acini

- Alpha \& Beta cells are getting aggregated amidst the acini.

- Green coloured Delta cells were observed from 17 weeks onwards

- Delta cells are smaller than Alpha and Beta cells

- Delta cells are less in number.

- Plenty of mesenchymal cells with scattered rounded endodermal cells are seen which may form acini or islets

- $\quad$ Blood vessels seen near the Islets \& at other sites also 


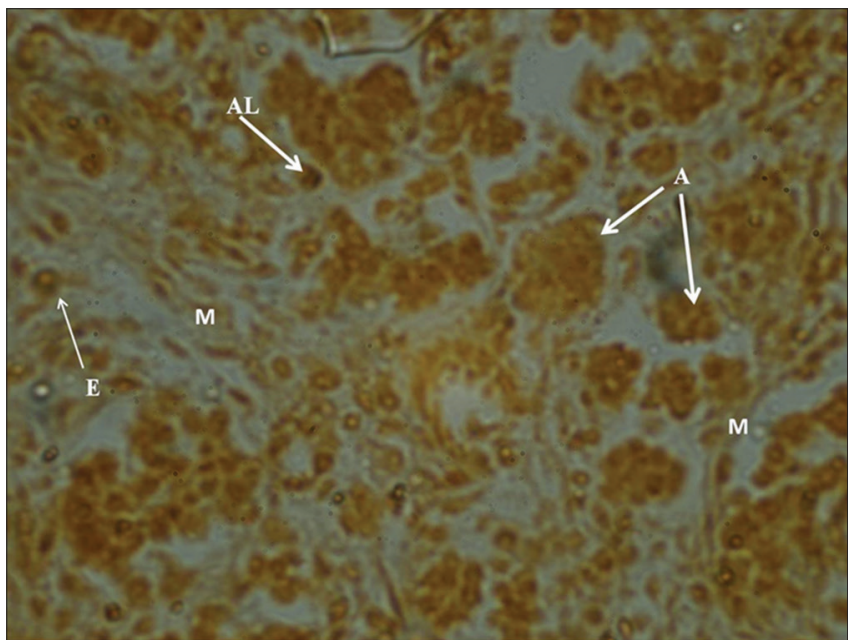

Figure 1: Human fetal pancreas of 10 weeks stained with Gomori's aldehyde fuchsin stain-oil immersion. A-Acini, AL-Alpha cell, M-Mesenchymal cell, E-endodermal cell

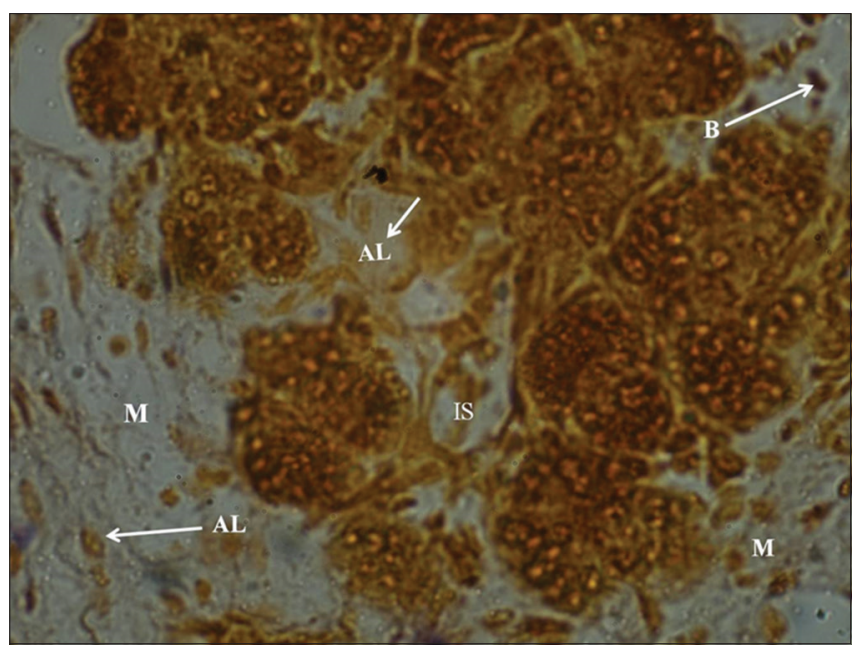

Figure 2: Human fetal pancreas of 16 weeks Gomori's aldehyde fuchsin stain-oil immersion. IS-Islet, M-Mesenchymal cell, B-Beta cell, AL-Alpha cell

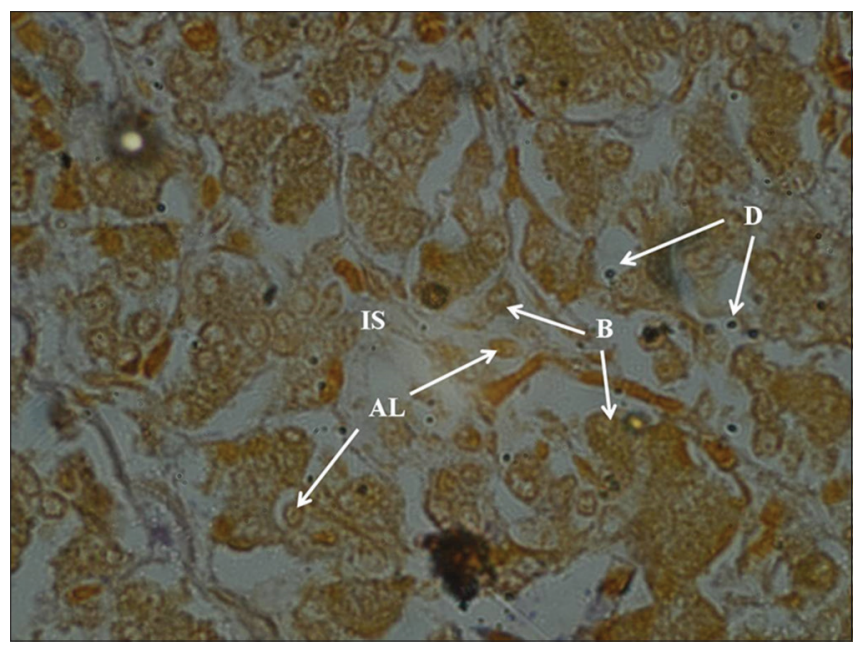

Figure 3: Human fetal pancreas of 17 weeks Gomori's aldehyde fuchsin stain-oil immersion. AL-Alpha cell, B-Beta cell, IS-Islet, D-Delta cell
19.1 weeks to 23 weeks foetus. (Figure 4)

- Alpha, Beta \& Delta cells are seen within the islets

- Groups of cells are seen inside a lobule amidst acini and forming Islets.

- Plenty of connective tissue with mesenchymal \& scattered rounded endodermal cells are seen

23. 1 weeks to 26 weeks foetus. (Figure 5)

- Well formed encapsulated Islets are seen

- Alpha \& Beta cells are seen arranged in the form of cord of cells

- Alpha cells, Beta \& Delta cells are seen in the Islets

- Also some of the scattered endodermal cells in the mesenchyme are seen as Alpha \& Beta cells

\section{1 weeks to 33 weeks foetus}

- Well developed encapsulated Islets are seen inside the lobules

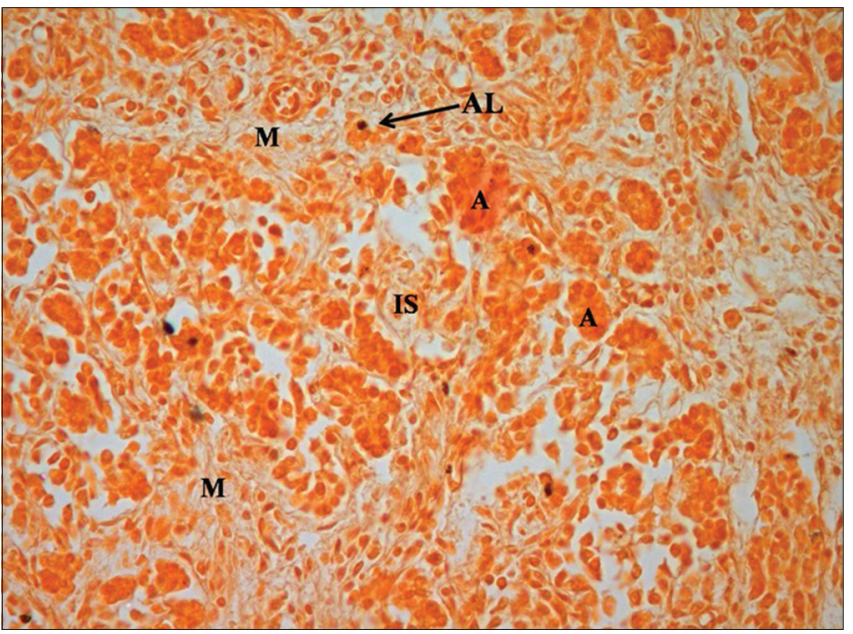

Figure 4: Human fetal pancreas of 19 weeks Gomori's aldehyde fuchsin stain-oil immersion. A- Acini, IS- Islet, M- Mesenchymal cell, AL- Alpha cell

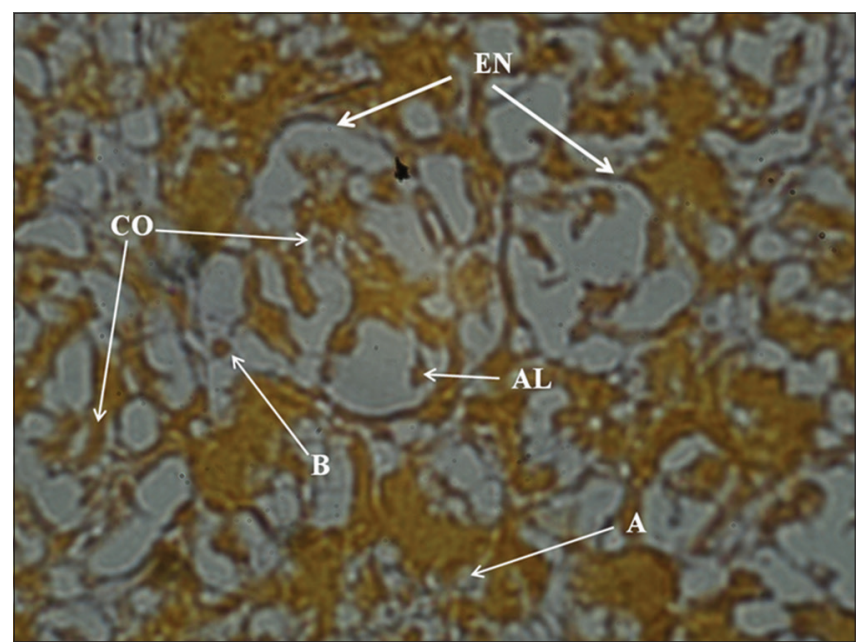

Figure 5: Human fetal pancreas of 26 weeks Gomori's aldehyde fuchsin stain-oil immersion. EN-Encapsulated islet, CO-Cords of cell, B-Beta cell, A-Acini, AL-Alpha cell

Asian Journal of Medical Sciences | Sep-Oct 2018 | Vol 9 | Issue 5 
- Alpha, Beta \& Delta cells are seen in the Islets arranged in groups \& cords

\section{1 weeks to 40 weeks foetus (Figure 6)}

- Encapsulated groups of cells are seen as islets of pancreas

- Alpha, Beta \& Delta cells are seen in the islets. Cells are arranged in the form of cords

- Alpha cells are larger in size than Beta cells whereas Beta cells are more in number as compared to the Alpha cells

- Delta cells are smaller than Alpha and Beta cells

- Delta cells are less in number compared to Alpha and Beta cells

- Scattered endodermal cells are still visible within the mesenchymal cells

\section{The following were the observations in nutshell} Islets

- Islets were initially a small number of cells with Alpha cells which were seen at 10 weeks in human embryos (Figure 1).

- Beta cells were identified in the islets of fetuses with 16 weeks gestation (Figure 2).

- Green coloured Delta cells were observed from 17 weeks onwards (Figure 3).

- Delta cells are smaller than Alpha and Beta cells.

- Delta cells are less in number.

- Islets appeared as a group of cells at 19 weeks (Figure 4).

- Encapsulations of Islets were noted at 26 weeks (Figure 5).

- Encapsulated Islets showed the number of Beta cells more than the Alpha cells.

- Alpha cells were larger in size than the beta cells.

- Arrangement of the cells inside the encapsulated Islets was seen in the form of cords of cells.

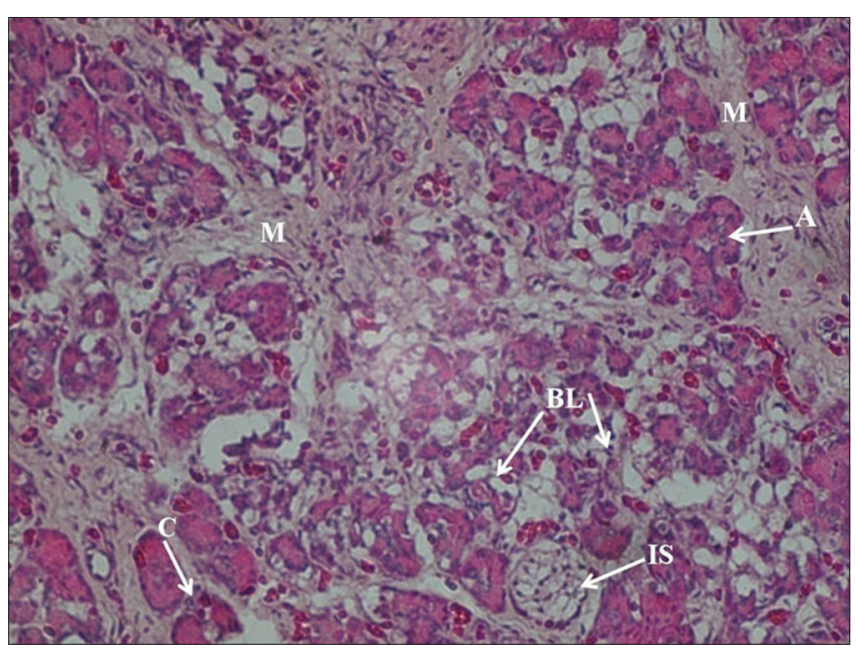

Figure 6: Human fetal pancreas of 36 weeks haematoxylin \& eosin stain. A- Acini, IS-Islet, M-Mesenchymal cell, C-Centroacinar cell, BL-Blood vessels
- Islets were not found budding from acini but they formed separately from endodermal cells within the lobules near acini or scattered in the mesenchyme.

- Blood vessels were seen penetrating the Islets.

\section{DISCUSSION}

Fetuses from 10 weeks up to 40 weeks of gestational age were procured for the present study, using routine as well as differential staining procedures and observed under high power \& oil immersion lenses. The selection of an appropriate developmental stage of fetal pancreas is of paramount importance for the successful transplant of pancreas in patients of insulin dependent diabetes mellitus. ${ }^{8}$. Vincent (1924)in his study with human foetuses described the islet as temporarily modified portions of zymogenous tissue. 'William Bloom (1931) using Mallory Heidenhain azan stain in human fetuses differentiated the Delta cells from the Alpha and Beta cells. ${ }^{10}$

The origin of pancreatic endocrine cells in the islet however is controversial ${ }^{8}$. It has been suggested that they arise from neural crest cells, ${ }^{11}$ and from epithelial cells of pancreatic ducts $^{12-14}$ or from cells in bone marrow ${ }^{15}$. Gupta et al. (2014) observed electron dense granules in the endocrine cells at the $14^{\text {th }}$ gestational weeks. ${ }^{8}$ Robb P (1961) in his study with human fetuses, reported the "mantle islet stage" at 12 weeksin which, a zonal arrangement of cells with Beta cells in the centre, and Alpha cells at the periphery was seen. ${ }^{16}$ Conklin (1962) in his study with human fetuses found the Islets to be connected to the tubules. Islets were identified in a $54 \mathrm{~mm}$ (9-12 weeks) fetus as clusters of small eosinophilic cells attached to the tubule but after vascularization, it got separated from the tubules by an encroachment of connective tissue. ${ }^{17}$

Like and Orci (1971)in their study of human fetuses identified the islets. The first islet cell type to have appeared was Alpha cell at 11 weeks. ${ }^{18}$ In the present study the Alpha cells started appearing in the islets around 10 weeks of gestation. The human fetal pancreas is a potential source of islet tissue for transplantation was suggested by Sutherland et al. (1976) after his study. ${ }^{19}$ Saito et al. (1978) studied the topographical differences of size, distribution, number and volume of islets in human pancreas. He found that the head of the pancreas had abundance of islets compared to the tail region. ${ }^{20}$

Hopcroft et al. (1985) in his study of the structural and functional relations of human pancreatic islets propounded that both direct intercellular communication and hormonal secretion by islet Alpha and Delta cell play a role in modulation of Beta cell function. ${ }^{21}$

Gupta et al. (2002) opined that the Islets originated from the tubules and subsequently established their independent 
identity. The first islet cell was identified at 12 weeks, 2 cell types were seen with acidophilic and basophilic cytoplasm and termed as 'A' and 'B' cells respectively. Dense aggregation of granules was seen in Alpha and Beta cells of $22-24$ weeks fetuses which might be having association with the amount of insulin secreted by them. ${ }^{1}$ The appearance of first Islet cell groups was well defined around $18-24$ weeks of gestation in the centre of the pancreatic tissue. The cell buds destined to form Islets were seen enclosed in groups of capillaries around $30^{\text {th }}-40^{\text {th }}$ week. ${ }^{22}$ In the present study, Islets were not found budding from acini but they formed separately from endodermal cells within the lobules near acini or scattered in the mesenchyme. It is also observed, the present study that from the scattered rounded cells in the mesenchyme, group of cells get formed which develop into pancreatic acini whereas initial scattered cells or the groups of cells later are arranged as cords of cells which form islets and get encapsulated. Also Alpha cells develop earlier than Beta cells in the islets and Delta cells were observed from 17 weeks. Delta cells are smaller than Alpha and Beta cells and are less in number. We also observed that encapsulation of islets were noted around 26 weeks. Further the encapsulation of islets showed the number of Beta cells more than the Alpha cells, Alpha cells were larger in size than the beta cells and arrangement of the cells inside the encapsulated Islets was seen in the form of cords of cells.

\section{CONCLUSION}

In the present study we observed a sequential development of Alpha, Beta and Delta cells and subsequent grouping of the islets. The exact gestational time of appearance of above islet cells and their encapsulation can add to the existing knowledge data base for successful transplant of pancreas in patients of insulin dependent diabetes mellitus.

\section{REFERENCES}

1. Gupta V, Garg K, Raheja S, Choudhury S and Tuli A. Histogenesis of Islets in the human foetal pancreas. J Anat Soc of Ind 2002; 51: 23-26.

2. Borley NR. Gray's Anatomy. 39th edition. New York, Churchill Livingston; 2006: 1231- 1238.

3. Centers for Disease Control and Prevention. National diabetes fact sheet: general information and national estimates on diabetes in the United States, 2005. Atlanta, GA: U.S. Department of Health and Human Services, Centers for Disease Control and Prevention. https://www.cdc.gov/diabetes/pubs/pdf/ndfs_2011.pdf.
4. Last RJ. Last's anatomy- regional and applied. 9 9 $^{\text {th }}$ edition. Edited by R.M.H.Mc. Minn. Churchill Livingstone Publication. London.1994: 351-353.

5. Bannister LH, Berry MM, Collins P, Dyson M, Dussek JE and Ferguson MWJ. Gray's anatomy. The anatomical basis of medicine \& surgery. $38^{\text {th }}$ edition. Churchill Livingstone Publication. Robert Stevenson house London.1995: 186-187.

6. Eroschenko VP. Di Fiore's Atlas of Histology with functional correlations- $8^{\text {th }}$ edition. Moscow, Idaho. Williams \& Wilkins publication. 1996. Pages: 228-232.

7. Gomori G. Observations with differential stains on human islets of langerhans. Am J Pathol 1941; 17: 395-406.

8. Gupta R, Satyanarayan S and Ashish NK. The histogenesis of developing human fetal pancreas an electron microscopic study. IJBR 2014; 5(11): DOI: https://doi.org/10.7439/ijbr.v5i11.809.

9. Vincent $\mathrm{S}$. The relationship between the islets of Langerhans and the zymogenous tissue of the pancreas. $J$ of Clin Pathol 1924; 206: 947-948.

10. Bloom W. A new type of granular cell in the islets of Langerhans of man. Journal of Anat Rec 1931; 49: 363-371.

11. Zulewski H, Abraham EJ, Gerlach MJ, Daniel PB, Moritz W, Muller B, et al. Multipotential nest in-positive stem cells isolated from adult pancreatic islets differentiate ex vivo into pancreatic endocrine, exocrine, and hepatic phenotypes. Diabetes 2001; 50: 521-533.

12. Bonner WS. Beta cell turnover: its assessment and implication. Diabetes 2001; 50 (1): 20-24.

13. Jorgensen MC, Ahnfelt- Ronne J, Madsen OD, Serup P and Hecksher- Sorensen J. An illustrated review of early pancreas development in the mouse. Endocr Rev 2007; 28: 685-705.

14. Setty $Y$, Cohen IR, Dor $Y$ and Harel D. Four dimensional relastic modelling of pancreatic organogenesis. PNAS 2008; 105: 20374- 20379.

15. lanus A, Holtz GG, Theise ND and Hussain MA. In vivo derivation of glucose competent pancreatic endocrine cells from bone marrow without evidence of cell fusion. J Clin Invest 2003; 111: 843-850.

16. Robb P. The Development of islets of Langerhans in the human fetus. Quar J of Exp Phys 1961; 46: 335-343.

17. Conklin JA. Cytogenesis of human fetal pancreas. Am J of Anat 1962; 111: 181-193.

18. Like AA and Orci L. Embryogenesis of the human pancreatic islets; A light and electron microscopic study. J of Diabetes 1971; 21: 511-534.

19. Sutherland DER, Matas AJ, Steffes MW and Najarian JS. Infant human pancreas: A potential source of islet tissue for transplantation. J of Diabetes 1976; 25: 1123-1128.

20. Saito K, Iwama N and Takahashi T. Morphometrical analysis on topographical difference in size distribution, number and volume of islets in human pancreas. J of Exp Med 1978; 124: 177-186.

21. Hopcroft DW, Mason DR and Scott RS. Structure function relationships in pancreatic islets: support for intraislet modulation of insulin secretion. Journal of endocrinology 1985; 117: 2073-2080.

22. Ramani TV, Nagajyothi D, Saritha S, Gayathri P, Yesender M and Anjum A. Histogenic study of human foetal endocrine pancreas. IOSR-JDMS 2015; 14: 26-30.

\footnotetext{
Authors Contribution:

SSB- Concept and design of the study, review of literature, data collection, manuscript preparation; VA- Concept and design of the study and critical revision of the manuscript.

Orcid ID:

Dr. Smita Singh Banerjee - 는 https://orcid.org/0000-0003-2115-196X

Source of Support: Nil, Conflict of Interest: None declared.
} 